\title{
ІМПЛЕМЕНТАЦІЯ ДОСЯГНЕНЬ СУЧАСНОЇ ФІЗИКИ У НАВЧАЛЬНИЙ ПРОЦЕС ЧЕРЕЗ ПРОФЕСІЙНО ОРІЕНТОВАНІ ЗАДАЧІ
}

\section{Н. В. Стучинська, І. М. Новікова}

Національний медичний університет імені О.О.Богомольця

бульвар Тараса Шевченка, 13, м. Київ, 01601, Україна. E-mail: nvstuchynska@ gmail.com.

Теоретично обгрунтована необхідність модернізації змістової та процесуально діяльнісної частини освітнього процесу студентів вищих медичних навчальних закладів з урахуванням сучасних досягнень фізичної та медичної науки. Запропонована модель підготовки фахівця медичної галузі, у якій імплементація сучасних наукових досягнень у навчальний процес з медичної та біологічної фізики $є$ однією з пріоритетних складових. Модель реалізується у навчальному процесі через професійно орієнтовані задачі різного типу та різного рівня складності, дослідницьку роботу студентів. Проведено класифікацію задач, що використовуються в курсі медичної і біологічної фізики, обгрунтовано необхідність, роль, місце та функції задач кожного типу. Сконструйована структура робочих зошитів студента, яка спрямована на формування предметних компетентностей з медичної та біологічної фізики та фахової компетентності майбутнього лікаря. Ефективність розробленої методики розв'язування фахово спрямованих завдань і задач, які зорієнтовані на інтеграцію знань, перевірена емпіричними методами дослідження (оцінюванням навчальних досягнень, анкетуванням, опитуванням, спостереженням). Результативність методики імплементації наукових досягнень у навчальний процес була підтверджена науковою роботою студентів.

Ключові слова: медична та біологічна фізика, професійно орієнтовані задачі, самоосвітня діяльність, робочий зошит, фахові компетентності, наукова робота студентів.

\section{ИМПЛЕМЕНТАЦИЯ ДОСТИЖЕНИЙ СОВРЕМЕННОЙ ФИЗИКИ В УЧЕБНЫЙ ПРОЦЕСС ЧЕРЕЗ ПРОФЕССИОНАЛЬНО ОРИЕНТИРОВАННЫЕ ЗАДАЧИ}

\section{Н. В. Стучинская, И. Н. Новикова}

Национальный медицинский университет имени А.А. Богомольца

бульвар Тараса Шевченко, 13, г.Киев, 01601, Украина. E-mail: nvstuchynska@ gmail.com.

Теоретически обоснована необходимость модернизации содержательной и процессуально деятельностной части образовательного процесса студентов высших учебных заведений с учетом современных достижений физической и медицинской науки. Предложена модель подготовки специалиста медика, в которой имплементация современных научных достижений в учебный процесс по медицинской и биологической физики является одной из приоритетных составляющих. Модель реализуется в учебном процессе через профессионально ориентированные задачи разного типа и разного уровня сложности, исследовательскую работу студентов. Проведена классификация задач, используемых в курсе медицинской и биологической физики, обоснована необходимость, роль, место и функции задач каждого типа. Сконструирована структура рабочих тетрадей студента, которая направлена на формирование предметных компетентностей по медицинской и биологической физике и профессиональной компетентности будущего врача. Эффективность разработанной методики решения профессионально направленных задач и задач, которые ориентированы на интеграцию знаний, проверена эмпирическими методами исследования (оценкой учебных достижений, анкетированием, опросом, наблюдением). Результативность методики имплементации научных достижений в учебный процесс была подтверждена научной работой студентов.

Ключевые слова: медицинская и биологическая физика, профессионально ориентированные задачи, самообразовательная деятельность, рабочая тетрадь, профессиональные компетентности, научная работа студентов.

АКТУАЛЬНІСТЬ РОБОТИ. Стрімкий розвиток наукових галузей обумовив появу принципово нових методів діагностики, лікування і профілактики. До таких методів варто віднести оптичну томографію, електричну імпедансну томографію, магнітокардіографію і магнітоенцефалографію, методики отримання зображень з використанням випромінювань в терагерцовий і мікрохвильової частинах електромагнітного спектра. Набувають все більшого поширення радіонуклідні методи досліджень: однофотонна емісійна комп'ютерна томографія (ОФЕКТ) і позитронно-емісійна томографія (ПЕТ). Вчені передбачають, що невдовзі практичного застосування набуде молекулярна діагностика (molecular imaging), яка надасть можливості дуже раннього діагностування хвороб на основі виявлення «хворих» клітин або молекул [1].

Відчутними є здобутки українських вчених у га- лузі медичної та біологічної фізики. Створено нові біосумісні матеріали для використання в ортопедії i травматології, новітні способи оперативних втручань, відкриваються нові відділення нейрорадіології і радіаційної нейрохірургії (2010р. Інституті нейрохірургії НАМН України), розроблено унікальні медичні прилади (Харківській фізико-технічний інститут НАН України), які експортують до США. Україн має розробки світового рівня у галузі матеріалознавства та нанотехнологій: створено кульшовий суглоб шляхом напилення титану, який випробувано в Інституті ортопедії і травматології НАМН України, використовуються покриття 3 антибактеріальною дією на титан, апробовані покриття із наночастинками хрому та молібдену (Інституті патології хребта та суглобів НАМН України. Змінюються технології і методи лікування у хірургії: розроблено метод електрозварювання живих тканин, судин та 
нервів; плазмове зварювання і термоструминне зварювання тощо[2]. Все це обумовлює необхідність «систематичного оновлення змісту фізичної освіти, акумулювання передових наукових досягнень 3 урахуванням пріоритетів у розвитку сучасної медицини та фізики» $[3,4]$; тобто модернізацію змістової та процесуально-діяльнісної частин навчального процесу, з урахуванням сучасних досягнень фізики.

Мета дослідження полягає в теоретичному обгрунтуванні оновлення змістової частини освітнього процесу 3 урахуванням сучасних наукових досягнень, розробленні та експериментальній перевірці технологічної моделі формування фахової компетентності майбутніх лікарів засобами задач з медичної фізики.

В основу дослідження покладено таку гіпотезу: застосування технологічної моделі навчальної діяльності, підгрунтям якої стане імплементація досягнень сучасної фізики через професійно оріснтова$\boldsymbol{\mu i}$ задачі, дасть змогу значно підвищити рівень знань студентів та сприятиме підвищенню якості навчальної діяльності на клінічних кафедрах та у майбутній медичній практиці.

Завдання дослідження:

- визначити коло питань, у яких має бути обізнаний студент-медик, а також ключові елементи фахової підготовки, які орієнтовані на майбутню професійну діяльність, та покласти їх у підгрунтя завдань різного типу;

- розробити авторську модель навчальної діяльності та систему організації самостійної навчальної діяльності засобами задач, яка б грунтувалася на інтеграції фундаментальної та фахової підготовки студентів і відповідала умовам кредитно-модульної системи організації навчального процесу [3].

- обгрунтувати роль, місце та функції завдань кожного типу, сконструювати структуру робочих зошитів, які спрямовували б навчальну діяльність на формування фахової компетентності майбутнього лікаря;

- експериментально перевірити дієвість технологічної моделі навчальної діяльності 3 формування фахової компетентності майбутніх лікарів $[5,6]$ засобами задач, підгрунтям яких є сучасні наукові досягнення з медичної та біологічної фізики.

Здобутки сучасної фізики, які складають основу багатьох діагностичних та лікувальних методів, вимагають розуміння ї сутності майбутніми лікарями. Тому організація освітнього процесу потребує системного оновлення як у змістовій, так і процесуально діяльнісній частині задля оперативного опанування студентами визначальними для сучасної медицини новітніми науковими досягненнями. Зокрема, через:

поглиблення змістової частини та імплементацію досягнень сучасної фізики та медицини в навчальний процес з дотриманням принципу науковості;

добору професійно орієнтованих задач, які забезпечують системність знань та практичну спрямованість матеріалу з опорою на сучасні досягнення науки;
- здійснення науково-дослідницької роботи студентів, яка сприяє розвитку наукового стилю мислення, розвитку критичного мислення та посиленню міждисциплінарних зв'язків;

- використання IКТ та хмарних технологій в організації освітнього процесу.

МАТЕРІАЛ I РЕЗУЛЬТАТИ ДОСЛІДЖЕНЬ. Аналіз підручників та збірників задач і запитань 3 медичної фізики багатьох авторів (О.В.Чалий; Я. Й. Лопушанський; В. О. Тиманюк, Е.І. Личковський, та ін.) свідчить, що у більшості 3 них добре описані теоретичні відомості, надана велика кількість задач, структурованих за темами. Проте жоден 3 них не дає відповіді на такі важливі питання: як результативно організувати аудиторну і самостійну роботу студентів, як логічно сконструювати навчальний матеріал, систему задач і вправ, які завдання, у якій кількості та послідовності треба вирішувати і чому задля отримання бажаних результатів при мінімальних витратах часу. А найголовніше - який результат ми бажаємо отримати. Пошук відповіді на ці питання $[3,4,7,8,9]$ спонукав нас до розроблення спеціального навчально-методичного забезпечення для семінарів-практикумів за різними темами - робочих зошитів для студентів. За допомогою саме цих посібників відбувається конструювання навчального процесу з використанням сучасних технологій навчання [5, 6, 8].

Робочий зошит до кожної з тем структурований відповідно до цілепокладання. На початку зошита описана мета, спеціальні, загальні та фахові компетентності, яких має набути студент; перелік знань, навичок, які мають сформуватися у процесі навчальної діяльності; основні поняття теми; система міждисциплінарних зв'язків та рекомендована до опрацювання література.

При організації роботи студентів з розв'язування задач вважаємо, що бажаним результатом має стати: формування основ фахової компетентності, навичок самостійної роботи, наукового та критичного стилю мислення; запобігання суто формальному вивченню матеріалу, завдяки орієнтуванню на подальше його використання у фаховій діяльності. Результат забезпечується за рахунок упровадження системи спеціально підібраних завдань, сучасних технологій, використання спеціальних методичних прийомів диференціації й інтеграції знань, організації кооперативного навчання, технологій заелементного розв’язування задач.

Додатковим інструментом професійної взаємодії під час роботи з використанням посібників стає ділова комунікація, значущість якої зростає при використанні сучасних IКТ.

Організація ділової комунікації здійснюється за рахунок обміну науковою інформацією в процесі сумісної начальної діяльності з виконання системи вправ; спілкування за допомогою мови та знакових систем - семантичних конспектів; виконання завдань, систематизованих в посібниках.

«Ділова комунікація» - це перш за все обмін інформацією в процесі діяльності, спілкування і шляхи іiі сполучення. Ефективність комунікацій в організації визначає якість навчального процесу. Діяль- 
ність викладача спрямована на забезпечення цілеспрямованої і скоординованої роботи студентів для вирішення поставлених завдань.

Зміст, цінність і корисність інформації оцінюється іiі семантичною мірою. Виникає спроба виміру змісту повідомлень у формі суджень, що $є$ носіями знань, які можуть бути зрозумілі людині (семантична концепція інформації). Тому ключові, базисні питання теми необхідно виносити на обговорення, використовуючи евристичну бесіду, діалог, наукову доповідь.

Самостійна робота студентів починається 3 опрацювання теоретичних відомостей за рекомендованими підручниками. Другим етапом є самостійна робота над контрольними питаннями до теми. Далі студентам пропонується опрацювати теоретичні відомості у вигляді семантичного конспекту. Наприклад, конспект $з$ теми «Дослідження дисперсії імпедансу біологічних тканин» має містити ретельно проведений теоретичний аналіз поняття імпедансу, його складових та їх ролі у формуванні імпедансу, методів його визначення. Далі розглядаємо практичне застосування сучасних методів дослідження електричних властивостей біологічних тканин, їх фізичну сутність та діагностичну цінність. Наступним етапом роботи є складання опорного конспекту та питань до теоретичного матеріалу теми, що сприяє формуванню самостійності в опрацюванні теоретичної інформації та підвищенню рівня якості навчання.

Нова якість освіти вимагає акцентувати увагу на цінності інформації. Поряд з кількістю інформації важливішою $є$ іiі цінність - міра корисності для розвитку особистості фахівця, яка визначається іï актуальністю, що носить динамічний характер та базується на сучасних досягненнях фізичної науки. Інформація - це діюча, корисна, «працююча» частина знань. Тому на сучасному етапі освіти стає проблема упорядкування великого потоку інформації, iii сортування, спеціалізації та критичного оцінювання.

Швидкість та якість отримання і обробки інформації, впорядкування інформаційних потоків стає головною умовою розвитку особистості та підвищує рівень (якість) навчання.

Слід пам'ятати, що кількість інформації має обмежене евристичне значення. Тому теоретичний матеріал, наданий у посібниках у вигляді семантичних конспектів, дозволяє акцентувати увагу на найголовнішому, відкидаючи не суттєве для вирішення поставлених начальних завдань.

Самостійна підготовка до практичного заняття у поза аудиторний час починається 3 виконання завдань на повторення курсу фізики середньої школи, які є підгрунтям теми. Далі студенти виконують фахово спрямовані тестові завдання та надають розгорнуту відповідь на запитання. Тільки потім в аудиторний час студенти розв'язують різного типу завдання за матеріалом теми: задачі-питання, ситуаційні завдання, якісні, графічні, задачі-рисунки, розрахункові задачі за різними рівнями складності. Зміст навчального матеріалу у посібниках наскрізь насичений практико-орієнтованими завданнями.
Для того, щоб навчальний матеріал був засвоєний його зміст перекодовується на мову завдань, додаються ідеї конструювання та моделювання, що дозволяє формувати та розвивати у студентів загальну навчальну компетентність та ії складові (вербально-комунікативну та логіко-математичну компетентність) [10], які є підгрунтям фахової компетентності.

Цінність інформації, на думку авторів [11], визначається наявністю проб і помилок, що закладено на молекулярному рівні - процеси розпізнавання i відбору молекулярних структур, що виникають внаслідок теплового руху. Динамічна розпізнавальна система біосинтезу білка функціонує в статичному оточенні переробляючи його на динамічне. У загальному випадку робота динамічної біологічної системи - це реалізація закладених знань, інформації інструктивного, програмуючого значення, а також інформації, що міститься в біологічних макромолекулах нуклеїнових кислот і білків. Тому «опанування дисциплінами фізико-математичного циклу має виключне значення для формування когнітивних схем як узагальнених стереотипних форм зберігання набутого в певній предметній галузі досвіду, а саме для формування фахово орієнтованих компетентностей студентів медиків, що сприятиме подальшому опануванню матеріалом на наступних курсах медичних закладів вищої освіти.

Фізичне знання для майбутнього лікаря не $є$ універсальним, а має базуватися на професійних цінностях, але виражатися в фізико-математичних термінах (з використанням знаково-символічної системи). Тому в жодному разі (створюючи інформаційне навчально-методичне забезпечення) не можна нехтувати завданнями репродуктивного змісту, але не менш важливими $є$ професійно орієнтовані інтегровані завдання. На певних етапах формування особистості фахівця слід обов'язково використовувати евристичні та творчі завдання.

Різні типи завдань і задач мають різне значення та рівень застосовності. Усі завдання $є$ полі функціональними, вони мають: діагностичну функцію, навчальну, функцію розвитку, мотивації тощо. Розглянемо основні типи завдань (запитання, вправи, задачі), що використовувалися нами для оптимізації навчального процесу.

1. Навчальні тестові завдання, які є базою для формування здібностей відповідного рівня, знань, навичок та умінь, сприяють засвоєнню навчального матеріалу. Система навчальних тестових завдань допомагає у реалізації поточного контролю самостійної діяльності студентів, створює умови для само оцінювання та самоаналізу засвоєних знань, умінь i навичок.

Для підбору відповідних навчальних тестових завдань проводився аналіз змістової та процесуально діяльнісної складових навчального процесу 3 урахуванням принципу взаємозв'язку фундаментальної та фахової підготовки. Аналізувався зміст навчальної дисципліни, визначалися шляхи формування знань та способи їх вдосконалення, підбиралися тестові завдання різної форми та рівня склад- 
ності, здійснювалося їх упорядкування та групування.

Кожне тестове завдання проходило перевірку на валідність і підбиралося так, щоб воно перевіряло певний фрагмент знань та охоплювало питання, які виносяться до самостійного вивчення студентами. Зошити містять різноманітні навчальні тестові завдання закритої форми та тестові завдання на відповідність. Всі завдання можна використовувати в якості інструменту оцінювання та само оцінювання.

Приклад тестового завдання закритої форми. Продовжити речення, обравши правильну відповідь.

Тест 1. Електропровідність біологічних систем це...

А) дослідження наповнення кров'ю органу або частини тіла на підставі реєстрації змін їх електричного опору або діелектричних властивостей;

В) застосування різних видів електрики 3 лікувальною метою;

С) здатність живих тканин і організмів пропускати електричний струм під дією електричної напруги;

D) метод реєстрації опору тіла людини змінному струму.

Оновлення змістового наповнення завдань та задач тісно пов'язане $з$ міждисциплінарною інтеграцією, оскільки більшість тестових завдань, які формують основу загальнотеоретичного фундаменту професійної підготовки студентів, спирається на знання декількох дисциплін.

Приклади тестових завдань на інтеграцію знань. Продовжити речення, обравши правильну відповідь.

Тест 2. При проведенні допплерівської ехокардіографії спостерігається збільшення частоти відбитого сигналу наприкінці серцевого ритму в лівому шлуночку. Це явище може вказувати на те, що...

А) кров рухається у напрямку до зонда, що може свідчить про клапанну регургітацію;

В) кров протікає 3 постійною швидкістю, що відповідає нормальному серцевому стану;

С) кров рухається від зонда, що може свідчить про високий кров'яний тиск;

D) кров у серці рухається зліва направо, що вказує на можливий дефект серця.

Тест 3. При проведенні допплерівської ехокардіографії спостерігається більше, ніж зазвичай, зниження частоти відбитого сигналу. Це явище може свідчити про те, що...

А) здійснюється повільніший, ніж норма, відтік крові з серця, що вказує на можливе зниження артеріального тиску (гіпотонія);

В) здійснюється швидший, ніж норма, відтік крові 3 серця, що вказує на високий кров'яний тиск (гіпертонія);

C) кров здійснює потік у зворотному напрямку до приймача при закритих клапанах (регургітаційні серцеві клапани);

D) змінився нормальний напрямок потоку, що вказує на можливе неправильний кровообіг між камерами серця.

Приклад тестового завдання на відповідність.

Тест 4. Встановіть відповідність між назвою діагностичного методу та її визначенням:
1) реографія...

2) реоенцефалографія.

3) реокардіографія...

А) дослідження кровообігу мозку

В) реєстрація зміни імпедансу біологічної тканини в процесі пї діяльності

С) дослідження серцевого кровообігу

2. Задачі-запитання. Запитання є «окремим видом завдання коли воно спрямоване на одну зі сторін навчальної діяльності: змістову, операційну чи мотиваційну,.. складова частина умови задачі» (Машбиц Е.І.), «знакову модель вимоги пізнавальної чи комунікативної задачі (Г.О. Балл.), «форма пізнавального завдання» (М.С. Пак) [12]. Задачізапитання це такі завдання, які $є$ клітинкою навчальної діяльності, елементом змісту, засобом навчання та можуть носити проблемний характер, якщо студент усвідомлює мету запитання, але не знає способів їі досягнення.

Наприклад: «Наведіть чинники, які відіграють істотну роль у зміні електричних властивостей живих клітин і тканин?», «Для чого в клінічній практиці використовують метод дослідження дисперсії імпедансу?» «Поясніть на чому грунтується метод дослідження дисперсії імпедансу?», «При яких фізіологічних станах змінюється активний опір, реактивний, ємнісний опір? Обгрунтуйте твердження.» тощо.

3. Ситуаційні і мета-задачі. Ситуаційні задачі використовуються з метою опису деякою ситуації за деякою темою курсу. Мета-задачі - це задачі, які вимагають опису ситуації або складання ситуаційної задачі з певної теми курсу.

Наприклад. Мета-задача: «Скласти ситуаційну задачу за темою імпеданс». Ситуаційна задача: «У центр трансплантології був доставлений біологічний матеріал для пересадки реципієнту. Для визначення якості та життєздатності тканини використовувався метод дослідження електропровідності. Виявилося, що коефіцієнт дисперсії імпедансу біологічної тканини цього органу має значення близьке до одиниці. Чи можна використовувати таку тканину для трансплантації?»

4. Якісні задачі. Розв’язування якісних задач передбачає побудову умовиводів на основі застосування фізичних теорій і законів, без застосування математичного апарату [13].

Під якісною навчально-пізнавальною задачею 3 фізики слід розуміти задачу, в якій ставиться проблема, пов'язана $з$ якісною стороною розглядуваного фізичного явища і розв'язується шляхом логічних розумових дій, побудови графіка, виконання експерименту, але без застосування математичних дій». «Увага в них акцентується на якісній характеристиці розглядуваного фізичного явища» [13].

В нашому посібнику використовуються якісні задачі різного типу: різні за ступенем складності (від простих якісних запитань до складних і творчих), різні за характером проблеми (пояснення, передбачення явищ, порівняння явищ у якісному відношенні, визначення умов протікання явищ, встановлення закономірностей, систематизацію і класифікацію понять та ін.), різні за змістом, за способом подання умови (текстова, наочна, графічна, експе- 
риментальна), за прийомами розв'язання, за співвідношенням між умовою і вимогою задачі, за ходом міркувань та ін. [13].

Наприклад. «Чим визначаються електричні властивості живих тканин?», «При набряках тіла спостерігається різкий спад опору електричного струму. Пояснить це явище.», «Які тканини організму людини мають: а)найкращу електропровідність; б) найнижчу електропровідність?», «При вимірюванні питомого опору різних речовин - жирової тканини; сухої шкіри; крові; спинномозкової рідини; кістки без окістя - отримано такі дані (в Ом м): 0,$55 ; 1,7$ : $33 ; 10^{5} ; 10^{7}$. Який питомий опір: а) крові; б) сухої шкіри; в) спинномозкової рідини; г) жирової тканини; д) кістки.»

\section{5. Кількісні задачі.}

Далі пропонується самостійно розібрати та опрацювати повністю приклад розв'язання однієї, або двох, задач та записати іiі у зошиті. Після чого пропонуються кількісні задачі для самостійного розв'язання різних рівнів складності, від простіших до складних. Робота $з$ опрацювання задач здійснюється відповідно до розробленої технології [5,6]. До кількісних відносяться задачі, відповіді на запитання яких не можуть бути знайдені без виконання математичних перетворень і обчислень [12,13]. Вони підібрані від найтиповіших, які розв'язуються разом із викладачем фронтально і потім оформлюються студентом у зошиті, до інтегративних, які потребують знань 3 декількох тем та складних математичних розрахунків.

Наприклад.

Задача 1. Розрахуйте силу струму крізь біологічну тканину, якщо при напрузі 0,17 В $\dddot{11}$ імпеданс дорівнює 51000000 к Ом.

Задача 2. На частоті $\mathcal{V}=10$ кГц опір серцевого м'яза $\mathrm{R}_{1}=600$ Ом; на частоті $\mathcal{V}=1 \mathrm{MГц}-\mathrm{R}_{2}=200$ Ом. Знайти коефіцієнт поляризації.

Задача 3. При хронічному пост енцефалітному паркінсонізмі реактивний ємнісний опір підкіркової структури $\mathrm{X}_{\mathrm{c}}=17,7$ кОм, зсув фаз між струмом $\mathrm{i}$ напругою $\varphi=30^{\circ}$. Знайти імпеданс Z.

6. Експериментальні задачі. За результатами анкетування студентів найбільш цікавими та корисними для подальшої практичної діяльності є експериментальні завдання (67\%) та задачі, постановка та розв'язування яких тісно пов'язані з експериментом. Вони сконструйовані та спрямовані на засвоєння понятійного (опанування головних понять, законів, теорій), операційного (вчать порівнювати, аналізувати результати експерименту та робити узагальнення і висновки) апаратів фізики, сприяють формуванню та розвитку навиків самостійної діяльності студентів.

Приклад експериментального завдання спрямованого на відпрацювання понять і встановлення зв'язків між ними.

Завдання 1. За отриманими даними прямих вимірів декілька груп студентів (маса тіла, зріст, об’єм легень) сформувати вибіркові сукупності: маса тіла студентів групи, зріст, об'єм легень.

Завдання 2. Для вказаної викладачем вибіркової сукупності побудувати інтервальний ряд розподілу й гістограму відносних частот. Зробити точкову оцінку параметра, що був вибраний для дослідження. Зробити інтервальну оцінку істинного значення вимірюваної величини 3 довірчою ймовірністю $\Upsilon=$ 0,95 .

Завдання 3. Для пари вибірок (маса тіла, об'єм легень; маса тіла, зріст) побудувати кореляційну таблицю та кореляційне поле. Обчислити вибірковий коефіцієнт парної кореляції. Оцініть вірогідність коефіцієнта кореляції. 3'ясувати кореляційну залежність пари випадкових величин, що була досліджена.

Останнім етапом 3 розв'язування задач для студентів стає складання проблемно-ситуаційних завдань 3 теми та надання на них відповідей. Важливість і необхідність яких підтверджено анкетуванням (12,5\%). В якості творчого завдання пропонується самостійно скласти задачу та розв'язати ऑіi; навести приклади практичного застосування вивчених знань в діагностиці та лікуванні у вигляді конспекту, схем, таблиць тощо; обрати тему для доповіді та підготувати тези до конференції. Коло наукових тематичних досліджень студентів обумовлено сучасними потребами суспільства та розвитком науки.

Використання посібників для студентів на друкованій основі та знаково-символічних засобів (семіозису - знакового процесу) створюють інформаційну основу діяльності студентів. Оперування знаково-символічними засобами $є$ одним з видів знаково-символічної діяльності студентів, який з успіхом нами застосовується, це - заміщення, кодуваннядекодування, схематизація, моделювання. Підібрані в певній послідовності завдання створюють інформаційну основу діяльності студентів, забезпечують наступність та системність знань, створюють систему орієнтирів для самостійної діяльності, залучають до активної пізнавальної діяльності та виступають засобом управління навчальним процесом. Система вправ і завдань, підгрунтям яких є сучасні досягнення науки, побудована на диференційованій основі. Освітній процес реалізується у двох площинах - у площині прямого навчання (використовуючи робочі зошити, систему та технологію розв'язування задач, дискусії ...) та у фоновому режимі (через наочність, IКТ, хмарні технології, наукову діяльність студентів тощо), що ставить нові вимоги до освітнього середовища та організаційнометодичного забезпечення процесу навчання, оскільки при цьому залучаються потужні сфери несвідомого. Зокрема збагачується досвід зорового впізнавання, набувається досвід виконання окремих предметно-практичних дій.

Аналіз анкетування студентів показав, що $86,36 \%$ студентів вважають необхідним та важливим розв'язування фахово спрямованих завдань i задач, які зорієнтовані на інтеграцію знань. Особливу зацікавленість викликають задачі, підгрунтям яких $\epsilon$ сучасні досягнення фізичної та медичної науки. Найбільш результативними формами роботи студентів $\epsilon$ самостійна робота студентів за робочими зошитами з опрацювання теоретичних відомостей, розв'язування різного типу завдань (87\%). При розв'язуванні задач перевага надається фронталь- 
ному розв'язуванню задач (47\%) та груповій або парній роботі (75\%)., самостійне складання задач за даною темою - $12,5 \%$.

Установлено, що організація самостійної навчальної діяльності студентів, за розробленою моделлю, активує творчий потенціал студентів, підвищується рівень навчальних досягнень 3 фізики на 15\%. Значно підвищується рівень наукової діяльності, за результатами тестування 26\% студентів вважають необхідним і важливим здійснення наукової діяльності 3 перших курсів, участь у конференціях та написання тез, що підтверджується участю студентів у роботі різних міжнародних науковопрактичних конференцій. Так, з травня 2017 року по травень 2018 року студентами, які навчалися за розробленою моделлю, було опубліковано 26 тез доповідей за різними темами з медичної фізики.

ВИСНОВКИ. У роботі теоретично обгрунтовано, розроблено та апробовано модель методики навчання медичної та біологічної фізики, яка базується на:

- модернізації змістової частини освітнього процесу з медичної та біологічної фізики, підгрунтям якої $\epsilon$ імплементація досягнень сучасної науки через професійно орієнтовані задачі;

- поданні елементів змісту освіти у вигляді різнорівневих особистісно орієнтованих завдань («технологія задачного підходу») закладених у робочому зошиті для аудиторних та поза аудиторних занять студентів;

- засвоєння змісту в умовах діалогу як особливої форми дидактико-комунікативного середовища, що забезпечує суб'єктно-смислове спілкування, рефлексію, самореалізацію особистості (технологія навчального діалогу);

- створенні умов для переходу процесу освіти в самоосвіту, навчання в самонавчання, розвитку в творчий саморозвиток особистості.

Подальшим напрямком дослідження є удосконалення технологічної моделі навчальної діяльності з медичної фізики засобами задач на засадах досягнень фізичної науки.

\section{ЛІТЕРАТУРА}

1. Стучинська Н. В. Інтеграція фундаментальної та фахової підготовки майбутніх лікарів у процесі вивчення фізико-математичних дисциплін. Монографія. К.:Книга плюс, 2008. 409 с.

2. Богатирьова Р. В. Внесок сучасної науки у забезпечення розвитку охорони здоров'я. Науковий журнал МОЗ Украӥни. 2012. № 1. С. 6-15.

3. Новікова I. М. Сучасні тенденції організації навчально-виховного процесу. Наукові записки. Серія: Проблеми методики фізико-математичної і технологічної освіти. Част. 3. Вип. 5. За заг. ред. M. I. Садового. Кропивницький: РВВ КДПУ ім. В. Винниченка, 2014. С. 153-156.

4. Тараріна I. М. Педагогічна технологія як ін- струмент впровадження компетентнісно орієнтованого підходу в умовах профільного навчання: 3бірник матеріалів Міжнародної науково-практичної конферениії (м. Донецьк, 2 листопада 2010 р.), Донецьк, 2010, Том. 2, С. 170-176.

5. Стучинська Н. В., Новікова І. М. Проектування сучасного освітнього середовища на засадах особистісно орієнтованого та компетентнісного підходів. Наукові записки. Серія: Проблеми методики фізико-математичної і технологічної освіти. Частина 2. Випуск 10. За заг. ред. М.І.Садового. Кропивницький: РВВ КДПУ ім. В. Винниченка, 2016. C. $142-148$.

6. Стучинська Н. В., Новікова І. М. Технологічний підхід у процесі формування фахових компетентностей майбутніх лікарів засобами задач з медичної фізики. Теоретико-методичні проблеми виховання дітей та учнівськой молоді: зб.наук.праць. Тематичний випуск «Вища освіта України у контексті інтеграції до європейського освітнього простору». Вип. 21. Кн. 3. Том 1(75). К.: Гнозис, 2017. C. 224-236.

7. Тіщенко I. М. Генезис задачного підходу до навчання фізики. Науковий часопис національного педагогічного університету імені М.П.Драгоманова. серія № 5. Педагогічні науки: реалії та перспективи. Випуск 33: збірник наукових праць. За ред. проф. В. Д. Сиротюка. К.: вид-во НПУ імені М. П. Драгоманова, 2012. С. 181-186.

8. Тіщенко І. М. Сутність педагогічної технології в задачному підході до навчання. Віснік Чернісівського начіонального педагогічного університету імені Т.Г.Шевченка. Серія: Педагогічні науки. Випуск 109: збірник наукових праць. За ред. Носко М.О. Чернігів: ЧНПУ, 2013. С. 122-125.

9. Тіщенко І. М. Технологічна реконструкція задачного підходу до навчання фізики: материали за 9а международна научна практична конференция, «Образованието и науката на ХХІ век», 17-15 октомври, 2013.: Том 9. Педагогические науки. Психология и социология. София. «Бял ГРАД-БГ» ООД, 2013. С. $41-46$.

10. Ляшенко О. І., Раков С. А. Тест загальної навчальної компетентності: основні засади і результати пілотування. Педагогіка $i$ психологія. 2012. № 2. C. 27-35.

11. Рубин А. Б. Биофизика в 2-х томах. Том 1. М.: Издательство Московского университета, 2004. 917 c. C. $158-162$.

12. Староста В. І. Навчання школярів складати й розв'язувати завдання 3 хімії: теорія і практика: Монографія. Ужгород: УжНУ Гражда, 2006. 327 с.

13. Гончаренко С. У., Коршак С. В., Павленко А. І., Сергєєв О. В., Баштовий В. І., Коршак Н. М. Розв'язування навчальних задач з фізики: питання теорії і методики. За заг. ред. С. В. Коршака. К.: НПУ ім. М. П. Драгоманова, 2004. 185 с. 


\section{IMPLEMENTATION OF ACHIEVEMENTS OF MODERN PHYSICS IN THE EDUCATIONAL PROCESS THROUGH PROFESSIONALLY ORIENTED TASKS}

\section{N. Stuchynska, I. Novikova}

Bogomolets National Medical University

T. Shevchenko Boulevard, 13, Kyiv, 01601, Ukraine. E-mail: nvstuchynska@ gmail.com

The purpose of our research is to theoretically substantiate the need for updating the content of educational process of medical and biological physics in the light of modern scientific achievements; to develop and experimentally verify the effectiveness of the technological model for the formation of professional competence of future physicians using the means of professionally oriented tasks in the process of teaching medical and biological physics. Methodology. The problem-oriented analysis of the achievements of modern physics, which form the basis for many diagnostic and therapeutic methods, the achievements of Ukrainian scientists in the field of medical and biological physics and advanced scientific achievements in modern medicine have been applied. We have conducted the theoretical analysis of scientific and methodological literature, curricula, programs and textbooks on physics, written by different authors. The content and procedural activity of educational process has been analyzed. The model of using professionally oriented tasks has been carried out. The effectiveness of the developed methodology for solving professionally oriented tasks and those tasks, which are aimed at the integration of knowledge, has been verified by means of empirical methods of research (the assessment of academic achievements, questionnaires, surveys and observations). Results. We have substantiated the necessity of theoretical modernization of the content and procedural activity of educational process of students at higher medical educational institutions, taking into account the current achievements of physical and medical science. We have proposed the model of training of a specialist in the medical sphere, in which the implementation of modern scientific achievements into the educational process of medical and biological physics is one of the main components. The model is realized in the educational process through professionally oriented tasks of different types and various levels of complexity; and research work of students. We have classified the tasks used in the course of medical and biological physics; the necessity, role, place and functions of tasks of each type have been substantiated. We have constructed the structure of student's workbooks, which is aimed at forming the subject competence at medical and biological physics and the professional competence of future physician. The effectiveness of methodology of the implementation of scientific achievements in the educational process has been confirmed by students' scientific work. Originality. We have developed the model of educational activity and the system of organization of students' self-work educational activity using the means of professionally oriented tasks. We have provided the elements of the content of educational process in the form of multi-level personally oriented tasks ("the technology of the task approach"), which are implemented in the educational process using educational and methodological books (student's workbooks) on various topics for seminars-workshops and students' self-work. The structure of the educational process is based on the integration of the basic and professional training of future physicians and using modern teaching methods. Practical value. The selection of professionally oriented tasks ensures the systematic knowledge and practical orientation of the material, based on the modern scientific achievements. We have provided the acquisition of the content of education using dialogue, as a special form of the didactic-communicative environment, which provides the subjective-semantic communication, reflection and self-actualization of the individual ("the technology of educational dialogue"). The important conditions are created for the transition of education to self-education, learning to self-learning and the development to creative selfdevelopment of the individual. The activation of students' scientific and research work contributes to the development of the scientific style of thinking, the development of critical thinking and the strengthening of interdisciplinary connection. Conclusions. The methodology model of the teaching of medical and biological physics, which is aimed at the implementation of modern scientific achievements, using the means of professionally oriented tasks, has been theoretically substantiated, developed and tested. The further direction of the study is to improve the technological model of educational activity of medical physics using the means of tasks, which are based on the achievements of physical science. References 13 .

Key words: medical and biological physics, professionally oriented tasks, self-work educational activity, workbooks, professionally oriented competence, students' scientific work

\section{REFERENCES}

1. Stuchynska, N. (2008), «Integration of the fundamental and professional training of future physicians in the process of studying physical and mathematical disciplines», Monograph. K.: Book Plus, 409 p.

2. Bogatyreva, R. (2012), «The contribution of modern science to the development of health care», Scientific journal of the Ministry of Health of Ukraine. no.1, pp. 6-15. [in Ukrainian].

3. Novikova, I. (2014), «Contemporary trends in the organization of the educational process», Scientific Notes. Series: Problems of Methodology of PhysicalMathematical and Technological Education, Part 3, Issue 5, edited by Sadovyi, M., Kropivnitsky: RVV KDPU after V. Vynnychenko, pp. 153-156.
4. Tararina, I. (2010), «Pedagogical technology as an instrument for the introduction of a competenceoriented approach in the conditions of profile education», A collection of materials of the International Scientific and Practical Conference (Donetsk, November 2, 2010), Donetsk, Vol. 2, pp. 170-176 [in Ukrainian].

5. Stuchynska, N., Novikova, I. (2016), «The design of modern educational environment on the basis of personality-oriented and competency-based approaches», Scientific Notes. Series: Problems of Methodology of Physical-Mathematical and Technological Education, Part 2. Issue 10./ edited by Sadovyi, M., Kropivnitsky: RVV KDPU after V. Vynnychenko, pp. 142-148. 
6. Stuchynska, N., Novikova, I. (2017), «Technological approach in the process of formation of professional competencies of future doctors by means of tasks from medical physics», Theoretical and methodical problems of education of children and educational youth: the collection of scientific work, Thematic issue "Higher education of Ukraine in the context of inmigration to the European educational space", K.: Gnosis., vol. 21, kn. 3, vol. 1(75), pp. 224-236.

7. Tishchenko, I. (2012), «Genesis of a taskoriented approach to physical education», Scientific journal of the National Pedagogical University named after M. P. Drahomanov, Series no. 5, Pedagogical sciences: realities and perspectives. Issue 33: Collection of scientific works / edited by Syrotyuk V.D. K.: The form of the NPU named after M. P. Drahomanov, pp. 181-186.

8. Tishchenko, I. (2013), «The nature of pedagogical technology in the purposeful approach to learning», Visnyk of Chernihiv National Pedagogical University named after T. Shevchenko, Series: Pedagogical sciences. Issue 109: Collection of scientific works / edited by Nosco M.O. Chernigov: ChNPU, pp. 122-125.
9. Tishchenko, I. (2013), «Technological reconstruction of a task-oriented approach to the study of physics»: material for the 9th international scientific and practical conference, "Education for science and for the 21st century", 17-15 October, 2013.: Volume 9. Pedagogical sciences. Psychology and sociology, Sofia "Byal GRAD-BG" OOD, 2013. pp. 41-46.

10. Lyashenko, O. I., Rakov, S. A. (2012), «Test of general learning competence: basic principles and results of piloting», Pedagogics and Psychology, no 2. pp. 27-35.

11. Rubin, A. B. (2004), Biophysics in 2 volumes. Volume 1. M.: Publishing House of Moscow University, pp. 158-162.

12. Starosta, V. I. (2006), «Teaching students to compile and solve tasks in chemistry: theory and practice»: Monograph. Uzhhorod: UzhNU Grazhda, 327p.

13. Goncharenko, S. U., Korshak, E. V., Pavlenko, A. I., Sergeev, A. V., Bashtovy, V. I., Korshak, N. M. (2004), «Solving educational tasks in Physics: Questions of Theory and Methodology»/ edited by Korshaka, E.V., K .: NPU them. MP Drahomanov, p. 185.

Стаття надійшла 01.04.2019.. 